University of Nebraska - Lincoln

DigitalCommons@University of Nebraska - Lincoln

\title{
8-3-1984
}

\section{Sinking of Volcanic Ash in Uncompacted Sediment in Williams Lake, Washington}

Roger Y. Anderson

University of New Mexico, ryand@unm.edu

Edward Nuhfer

University of Wisconsin - Platteville

Walter E. Dean

U.S. Geological Survey, Denver, CO, dean@usgs.gov

Follow this and additional works at: https://digitalcommons.unl.edu/usgsstaffpub

Part of the Earth Sciences Commons

Anderson, Roger Y.; Nuhfer, Edward; and Dean, Walter E., "Sinking of Volcanic Ash in Uncompacted Sediment in Williams Lake, Washington" (1984). USGS Staff -- Published Research. 316.

https://digitalcommons.unl.edu/usgsstaffpub/316

This Article is brought to you for free and open access by the US Geological Survey at DigitalCommons@University of Nebraska - Lincoln. It has been accepted for inclusion in USGS Staff -- Published Research by an authorized administrator of DigitalCommons@University of Nebraska - Lincoln. 


\section{Sinking of Volcanic Ash in Uncompacted Sediment in Williams Lake, Washington}

Abstract. Volcanic ash from the eruption of Mount St. Helens on 18 May 1980 fell into Williams Lake in eastern Washington and was temporarily suspended at the sediment-water interface. After several months of compaction, the ash layer broke up and sank into lower density uncompacted lake sediment. Stratigraphic time displacements of several hundred years and a failure to recognize discontinuous ash layers in sediment cores are possible consequences of this process.

The ash from the 18 May 1980 eruption of Mount St. Helens settled into several lakes that were under the plume of tephra as it passed over south-central and eastern Washington (Fig. 1). The ash was subsequently compacted and the ash layer broke up and sank into the sediment beneath the ash.

The 18 May event provides an opportunity to examine the sinking of an ash layer in detail. For example, Welch et al. $(1,2)$ showed that an ash layer 3- to 4-cm thick in the deeper part of Moses Lake (reservoir), Washington, broke up after deposition and sank 5 to $6 \mathrm{~cm}$ below the sediment-water interface. The compacted ash layer in Williams Lake is 1.5 to 2 $\mathrm{cm}$ thick and in places has sunk nearly 1 $\mathrm{m}$ below the sediment-water interface.

Piston and gravity cores containing the 18 May ash layer were collected from various depths in Williams Lake in July 1983. In addition, the sedimentation rate in the lake has been measured by automated sediment traps since 7 August 1980. The information obtained is used to examine the rate of sinking of the ash and to estimate the chronostratigra- 


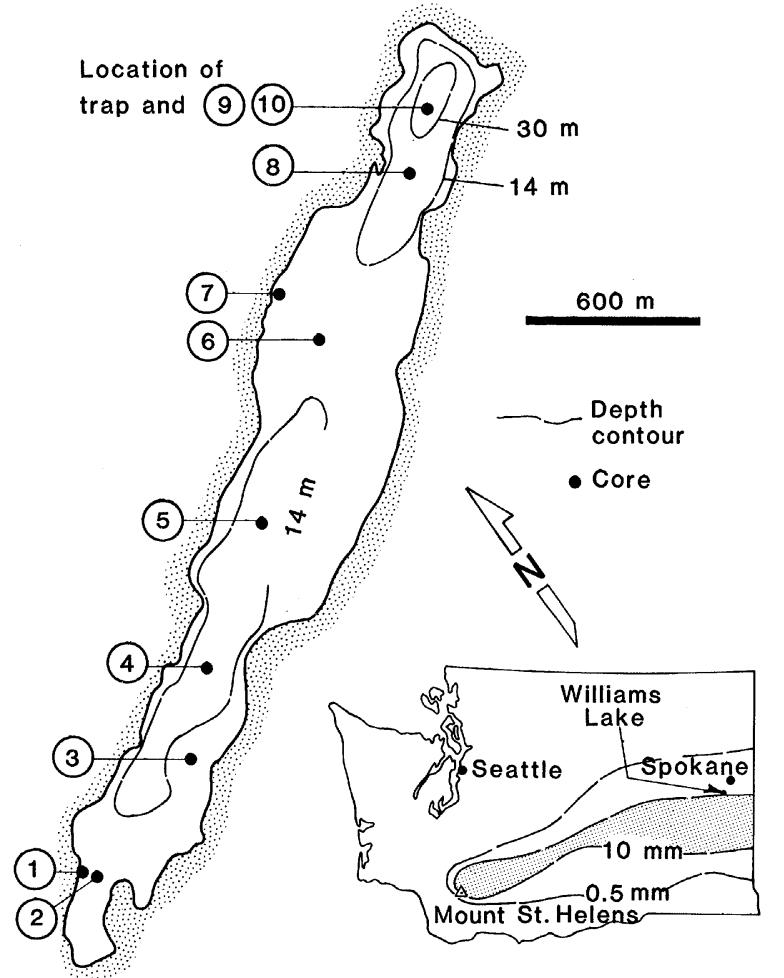

Fig. 1. Map of Williams Lake, Washington, showing bathymetry and location of cores and sediment trap, and map of Washington showing the path of the 18 May 1980 tephra plume (10).

phic error associated with this process.

Williams Lake is one of a number of small, elongate southwest-trending coulee lakes in the channeled scablands of west central Washington. The steepwalled lake basin was carved into underlying Miocene basalt during the catastrophic Spokane floods in the late Pleistocene. A shallow sill separates the smaller and deeper part of the lake from a larger, 15-m-deep basin (Fig. 1). The surface sediment in most of the lake, below water depths of about $10 \mathrm{~m}$, consists of black organic-rich sediment that grades downward, sometimes with a sharp transition, into olive-gray sediment. The sediment has the slight elastic consistency of gyttja and contains about 20 percent combustible organic matter, as determined by loss on ignition.

The ash layer is light to medium gray in color and has a tough, almost leathery, quality when bent, although it behaves brittlely when stressed further. The ash consists mainly of plagioclase fragments of andesine composition, irregularly shaped vitric particles, unaltered angular glass shards, commonly between 20 and $70 \mu \mathrm{m}$ in diameter, and impurities of organic detritus and diatom frustules. The ash layer has a water content of 39 percent by weight where it is encased in lake sediments and a bulk density of 1.6 $\mathrm{g} / \mathrm{cm}^{3}$. In contrast, the enclosing lake sediments are 86 percent water by weight and have a bulk density slightly greater than $1.0 \mathrm{~g} / \mathrm{cm}^{3}$. A profile of the organic content in the core from locality 5 shows that the change in color is not related to a decrease in organic content, and there is little vertical difference in water content or bulk density (Fig. 2).

Where there is little or no sinking, the ash forms a continuous, undeformed layer about 1.5 to $2 \mathrm{~cm}$ thick. Where sinking has occurred, the ash consists of tabular to irregular masses. The sunken masses found in the $5-\mathrm{cm}$-diameter cores range in size from about 1 to $4 \mathrm{~cm}$ in diameter. The identification of the 18 May 1980 ash collected in the cores is verified by index of refraction. In most of the cores the ash layer has broken up and sunk through the black organic-rich mud to about the contact with the olive-gray mud (Fig. 3). In the deepest part of the larger basin, the ash layer sank at least $40 \mathrm{~cm}$ into the olive mud beneath the black mud. The greatest depth to which masses of ash had penetrated was observed at core locality 5 , where $1-\mathrm{cm}$-size masses of ash were found $0.83 \mathrm{~m}$ below the sedimentwater interface. In the deeper basin, the ash layer sank only about $22 \mathrm{~cm}$ below the sediment surface. At intermediate water depths, and closer to shore, there was less sinking. Ash deposited in a shallow area of aquatic vegetation, where the sediment consists mainly of fibrous plant debris (core locality 7), did not sink at all.

Precautions were taken to ensure that

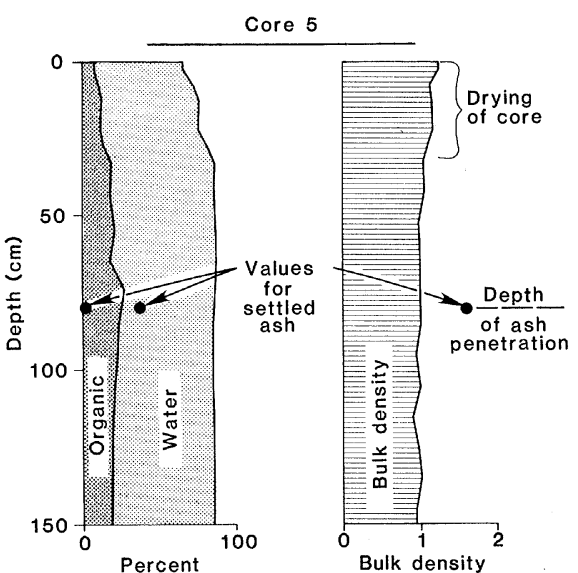

Fig. 2 (left). Profiles for water, organic content, and bulk density in core from locality 5 . Note contrast between ash and lake sediment. Loss of water content and increase in density at top of the core is the result of drying between coring and sampling. Fig. 3 (right). Profiles of cores collected in Williams Lake. Note that the ash layer is discontinuous and occurs at different depths in the cores. Without sinking, the ash would be only 1 to $2 \mathrm{~cm}$ below the sediment-water interface.

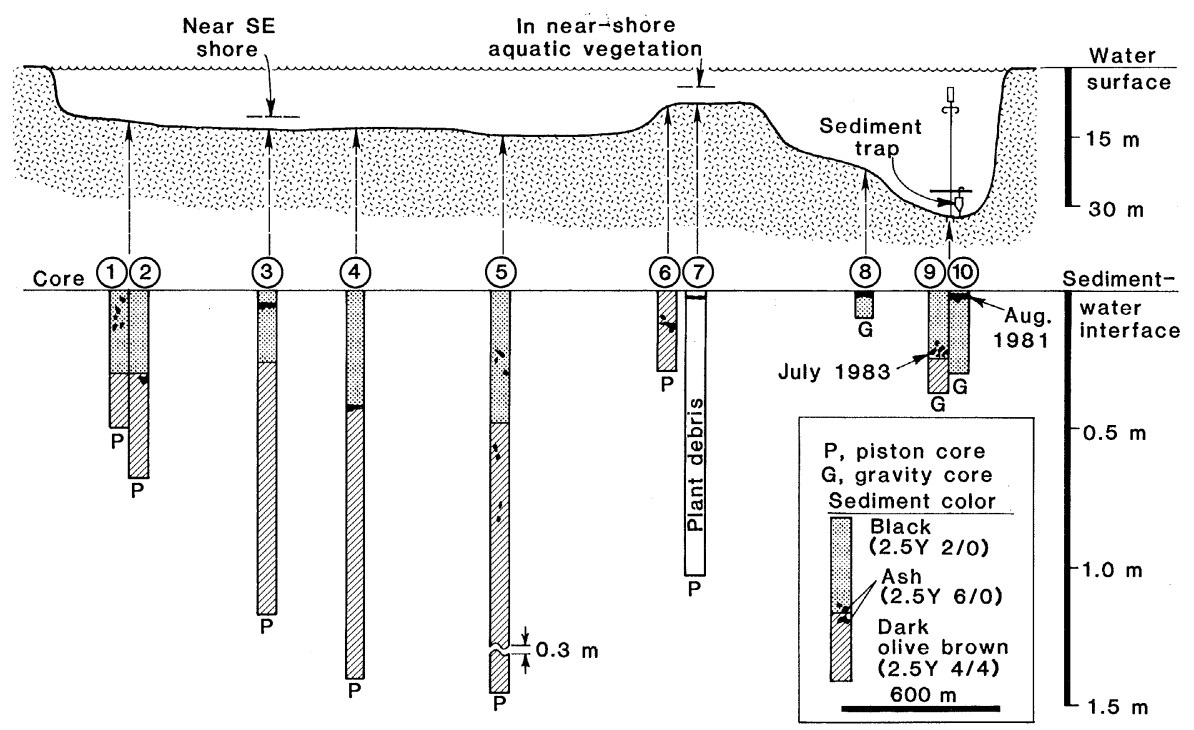


the ash was not dragged downward during the coring operation. Gravity cores were taken in the small deep basin, but piston cores, which offered little resistance to penetration, were taken at most localities (Fig. 3). Replicate cores taken at the same location showed the ash layer at the same depth. In addition, isolated masses of ash, less than half the diameter of the core tube, were collected from the center of core samples. Where these masses were encountered in green mud, they were encased in a rind of black mud, indicating that they picked up the rind from passing through the overlying black sediment after-breakup of the ash layer.

Ash from the 18 May eruption was recognizable as a single sheet shortly after deposition in Moses Lake $(1,2)$. The ash layer did not begin to break up and sink, at some of the collecting localities, until about 6 months after deposition. The layer of ash had largely stopped sinking after 2 years. In Williams Lake, a core taken at locality 10 in August 1981, more than a year after the eruption, contained ash that had penetrated no farther than $5 \mathrm{~cm}$ below the sediment surface. A core taken a few meters away in 1983 (locality 9) showed ash $22 \mathrm{~cm}$ below the sediment-water interface (Fig. 3). These data translate to rates of movement that range from about $2.5 \mathrm{~cm} /$ year in Moses Lake (2) to about $24 \mathrm{~cm} /$ year in Williams Lake.

The delay in breakup and sinking of the ash layer is probably related to the time required for compaction. The pore fluid in the newly settled ash layer probably supported the ash particles initially. However, without a significant clay fraction in the pore fluid this support would be relatively ineffective (3). Compaction and the extrusion of pore fluid increased the density and strength of the layer until it broke up and sank.

The reasons for the breakup of the ash layer are not obvious. Similar structures and shapes have been recognized in the sedimentary record (4) and have been produced experimentally, strictly from vertical settling of a coherent layer into less coherent material $(5,6)$. In the experiment, sinking was initiated after mild shaking to simulate earthquakes, and, presumably, fracturing of the coherent layer accompanied the shaking. Shaking was not a factor in the breakup of the ash layer in Williams Lake. However, differential loading, either from variations in the thickness of the ash layer or in overlying sediment, may have resulted in sagging of the ash layer. The ash layer encountered in the core samples is somewhat flexible but becomes brittle as strain is increased. This suggests that a sagging ash layer will eventually fracture.

Once the ash layer is broken, there will be little resistance to gravity-induced movement of the fragmented layer in the underlying sediment. The high water content and a density near 1.0 will

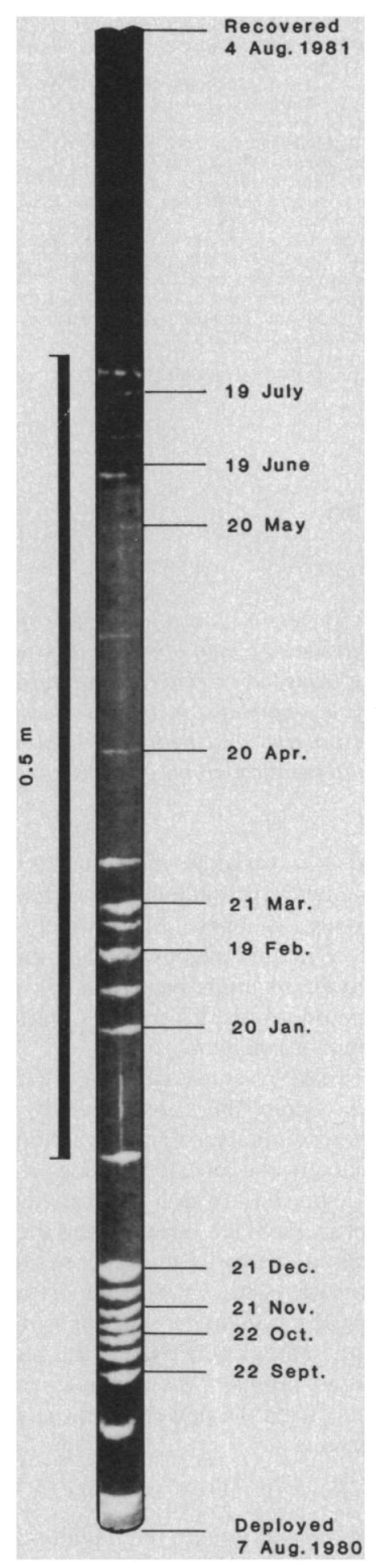

Fig. 4. Sediment column collected in trap at locality 9 in 1980 and 1981 . White layers are Teflon granules automatically inserted into the tube at 15-day intervals (7). A funnelshaped trap amplified the rate of sedimentation by a factor of $250 / 1$. result in a low yield strength, as compared to, for example, clay-water mixtures that exhibit debris flow after slumping (3). Downward movement will continue until internal friction and cohesion resist deformation by the descending mass. The minimum size fragment observed in the cores (1 $\mathrm{cm}$ in diameter) also reached the greatest depth $(83 \mathrm{~cm})$, and larger masses reached intermediate depths, suggesting that shape is a factor in determining resistance. The coulombviscous model is probably applicable to the flow of sediment around the ashlayer fragments. In this case, resistance to flow due to viscosity increases with the flow rate (3). This will favor the slow downward movement of the broken ash layer, as observed in Moses and Williams lakes.

The sinking of an ash layer can distort the time relationships of an ash event. The effect is to make the tephra layer appear older than it actually is. Some idea of the dislocation in time that is possible can be obtained from the Williams Lake example. Sediment traps have been maintained in the deepest part of Williams Lake (Figs. 1 and 4) since the summer of 1980 . The automated traps (7) amplify the rate of sedimentation and mark off equal increments of time with Teflon granules (Fig. 4). The thickness of lake sediment that accumulated in the trap between August 1980 and August 1981 is $0.37 \mathrm{~cm}$. The average for the $3-$ year period of observation is about 0.33 $\mathrm{cm} /$ year. If this rate is applied at core locality 9 , then a stratigraphic displacement whose time value is 60 years has occurred. At locality 5, in the larger basin, the displacement in time is about 250 years.

Williams Lake is not unusual in terms of the character of the bottom sediment. Conceivably, time displacements of 50 to several hundred years could be possible in other settings where fragmentation of the original ash layer can be demonstrated. This amount of displacement is not significant for ancient tephra events, but is important for events in the last few thousand years. The possible dislocation of an ash layer in time should also be considered in investigations to determine the impact of an eruptive event on vegetation (pollen), as measured in sediments that enclose an ash bed $(8)$.

The most important implication of the break up and settling of an ash layer is the potential for misinterpretation of tephra layers in core samples. Nodules and masses of coherent material are subject to oblique movement as they settle through less coherent material (6). This means that platelets and fragments from 
an ash layer can develop an imbricate pattern, leaving gaps in lateral continuity. Such gaps might account for failure to encounter an ash bed and for difficulties in the correlation of ash beds in drill cores (9). Missing ash beds could result in the misidentification of tephra layers where the criteria for recognition include the position or number of ash beds in a sequence.

Roger Y. ANDERSON

Department of Geology,

University of New Mexico,

Albuquerque 87131

EDWARD B. NuHFER

Department of Geosciences,

University of Wisconsin,

Platteville 53818

WALTER E. DeAN

U.S. Geological Survey,

Denver, Colorado 80225
References and Notes

1. E. B. Welch, M. D. Tomasek, S. B. Lazoff, in Proceedings of the conference on Mount St. Helens: Effects on water resources (Report 41, 1982), pp. 404-422.

2. E. B. Weich, M. D. Tomasek, D. E. Spyridakis, "Stability of the Mount Saint Helens" ashlayer in Moses Lake" (unpublished) (report of the Department of Civil Engineering, University of Department of Civil Engineering, University of
Washington, Seattle, 1983).

Washington, Seattle, 1983)

3. M. A. Hampton, J. Sediment. Pet. 42 (No. 4),

4. J. D. Sims, Tectonophysics 29, 141 (1975).

5. Ph. H. Kuenen, Trans. Geol. Soc. Glasgow 23, 1 (1958).

6. $\overline{\mathrm{Y} \mathrm{Y}}$, Geol. Mijnbouw 44e, 22 (1965).

7. R. Y. Anderson, Limnol. Oceanogr. 22, 423 (1977)

8. P. J. Mehringer, Jr., E. Blinman, K. L. Petersen, Science 198, 257 (1977).

9. J. D. Sims, in Paleolimnology of Lake Biwa and the Japanese Pleistocene, S. Horie, Ed. (1976), vol. 4, pp. 658-702.

10. A. M. Sarna-Wojcicki et al., U.S. Geol. Surv.

Prof. Pap. 1250 (1981), pp. 577-600. We are indebted to G. Del Mastro, L. Habenicht, L. Smith, and S. Adams for assistance in
the field and laboratory. Supported by NSF the field and labora
grant EAR81-13072.

27 February 1984; accepted 12 April 1984 